\title{
Evaluation Method of Drilling Fluid Inhibiting Performance
}

\author{
Shilin Zhao \\ Chongqing University of Science and Technology \\ Chongqing, China \\ zslcqust@126.com
}

Dongping Wang

Chongqing University of Science and Technology, Chongqing China

2660837784@qq.com

\author{
Jingfu Huang \\ Chongqing University of Science and Technology \\ Chongqing, China \\ 275910242@qq.com
}

\author{
Zhun Rong \\ Northeast Sichuan Gas Filed, Petro China Southwest \\ Oil and Gas Field Company \\ Dazhou, China \\ 651329775@qq.com \\ Wentao Cai \\ Chongqing University of Science and Technology \\ Chongqing, China \\ 282517348@qq.com
}

\begin{abstract}
To use high-quality drilling fluid to inhibit underground shale collapse, researchers must first evaluate many types of drilling fluid suppression performance. The method of evaluating the performance of the drilling fluid can be recovered by the rolling recovery test, the expansion of the drilling fluid, the sand bed, the immersion test, and so on. In this paper, through analysis of test inhibition performance of several samples in a variety of drilling fluid, the results show that the Rolling shale recovery test and mud filtrate linear expansion tests can be used to evaluate the dispersion and the expansion of the drilling fluid to inhibit shale; The test bed of sand can evaluate the sealing ability of drilling fluid; While according to the characteristics of the rock formations drilled with the appropriate soaking conditions to core immersion test that can make a comprehensive evaluation for the drilling fluid inhibition.
\end{abstract}

Keywords-Drilling Fluid; the Shale; Borehole Wall Collapse; Inhibitory; Evaluation Method

\section{INTRODUCTION}

The drilling fluid of anti-sloughing and rejection capability is one of the important conditions to evaluate the merits of the drilling fluid, and it is also the hotspot of research on drilling fluid at home and abroad. When drilling in mud shale formation, the problem of borehole instability is often occurs. To use high quality drilling fluid inhibition of underground shale, it must evaluate and inhibit the performance of various drilling fluid[1]. Therefore, domestic and foreign drilling workers have developed many evaluation methods of drilling fluid inhibiting properties, such as shale drilling are rolling recovery test, mud filtrate linear expansion test, the test bed of sand, soaking experiments[1 4]. Shale rolling recovery test can check the drilling fluid ability of inhibit the dispersion of shale; Mud filtrate linear expansion test can detect the drilling fluid ability of inhibit the expansion of shale .Sand bed test can detect drilling fluid ability of plugging fractured shale pore. The core soaking test can detect hydration results after the filtrate into the internal core, and also detect ability of drilling fluid to sealing shale fracture pore, and it can make a comprehensive evaluation on drilling fluid inhibition. However, shale soaking can be soaked in different conditions, different samples under different conditions immersion will have different conditions. In this paper, it analyzed the test result of several rocks in several drilling fluid inhibitory ability and discussed the Shortcomings of shale rolling recovery rate, and the sand bed test results were compared with the test results of core filtrate linear soaking expansion.

\section{THE FORMULATION AND PROPERTY OF TEST DRILLING FLUID}

\section{A. The formulation of drilling fluid}

In drilling fluid inhibition test researchers selected three kinds of drilling fluid system, it is sulfonated drilling fluid system, oil-based drilling fluid system and simulation oil-based drilling fluid system.

(1) Potassium polysulfonate drilling fluid system, the formulation is:

$0.05 \% \mathrm{KPAM}+3.5 \% \mathrm{SMC}+3.5 \% \mathrm{SMP}-2+0.5 \% \mathrm{LS}-$ $2+3 \%$ RLC- $101+3 \%$ Lubricant $+0.1 \% \mathrm{NaOH}+3 \% \mathrm{KCl}$.

(2) Simulation oil-based drilling fluid system

foumulation $1: 2 \%$ Clay $+0.4 \% \mathrm{MMCA}+0.5 \% \mathrm{PAC}-$ Lv+2.0\%DR-8 +8.0\%MEG+0.5\%DR-10+0.5\%HRH +3\% Super calcium $+\mathrm{KOH}$ regulating $\mathrm{PH}$

formulation $2: 2 \%$ Clay $+0.4 \% \mathrm{MMCA}+0.5 \% \mathrm{PAC}-$ $\mathrm{Lv}+2.0 \% \mathrm{DR}-8+8.0 \% \mathrm{MEG}+0.5 \% \mathrm{DR}-10+0.5 \% \mathrm{HRH}+3 \%$ Super calcium $+2 \% \mathrm{RLC}-101+\mathrm{KOH}$ regulating $\mathrm{PH}$ 
(3)Oil-based drilling fluid system the formulation is:

oil-water ratio $70: 30(5 \#$ white oil : $30 \% \mathrm{CaCl}$ aqueous solution) +2.5 histosol $+3 \%$ main emulsifier $+2 \%$ auxiliary emulsifier+lubricant $+3 \%$ filtrate reducer $+1.5 \% \mathrm{CaO}$

\section{B. The property of drilling fluid}

Potassium polysulfonate drilling fluid and oil base drilling fluid is drilling mud, imitation oil based drilling fluid is laboratory preparation, make property test and aging treatment ,three kinds of drilling fluid properties as shown in table 1 .

TABLE I. DRILLING FLUID SYSTEM PROPERTY

\begin{tabular}{|c|c|c|c|c|}
\hline $\begin{array}{l}\text { drilling fluid } \\
\text { sample }\end{array}$ & $\begin{array}{l}\text { Density } \\
(\mathrm{g} / \mathrm{cm} 3)\end{array}$ & $\begin{array}{c}\text { PV } \\
\text { (mPa.s) }\end{array}$ & $\begin{array}{l}\mathrm{YP} \\
(\mathrm{Pa})\end{array}$ & $\begin{array}{l}\text { Water } \\
\text { loss } \\
\text { (ml) }\end{array}$ \\
\hline $\begin{array}{c}\text { Potassium } \\
\text { polysulfonate } \\
\text { drilling fluid }\end{array}$ & 1.31 & 18 & 7.154 & 5 \\
\hline $\begin{array}{l}\text { oil-based drilling } \\
\text { fluid }\end{array}$ & 1.14 & 29 & 6.1 & 0 \\
\hline $\begin{array}{l}\text {. Imitation of oil- } \\
\text { based drilling } \\
\text { fluid I (aging } \\
\text { treatment) }\end{array}$ & 1.08 & 27 & 5.1 & 5 \\
\hline $\begin{array}{l}\text { Imitation of oil- } \\
\text { based drilling } \\
\text { fluid II (aging } \\
\text { treatment) }\end{array}$ & 1.08 & 26 & 4.5 & 4 \\
\hline
\end{tabular}

Through the comparison of several properties of the drilling fluid, it can be found that the plastic viscosity of polysulfonate drilling fluid is smaller, and the oil base drilling fluid loss is zero.

\section{EVALUATION TEST OF DRILLING FLUID INHIBITION}

\section{A. Rolling shale recovery test}

Shale rolling recovery test is mainly used to detect the capability of drilling fluid to the inhibiting of shale dispersion. It is also a direct way to quantitative evaluate fully expanded shale of dispersed size. The method is: grating the shale samples to through the $(6 \sim 10$ mesh $)$ sieve, then take $50 \mathrm{~g}$ samples and $350 \mathrm{ml}$ of test liquid into the heating tank. After that, put the tank into heating roller to heating furnace in rolling for 16 hours. Pour the liquid and the test specimen, through 40 mesh sieve, drying and weighing sieve samples, calculating the quality recovery rate (in percentage). Getting the above 40 mesh dry rock, placed in the heating tank with $350 \mathrm{ml}$ of water, continue to roll 2 hours, pour out the test liquid and the specimen, then 40 mesh sieve, drying and weighing samples, calculate the recovery percentage account for the original sample[5-6].

Four rock samples rolling 2 hours in water heating, determination of the shale recovery results shown in Fig. 1

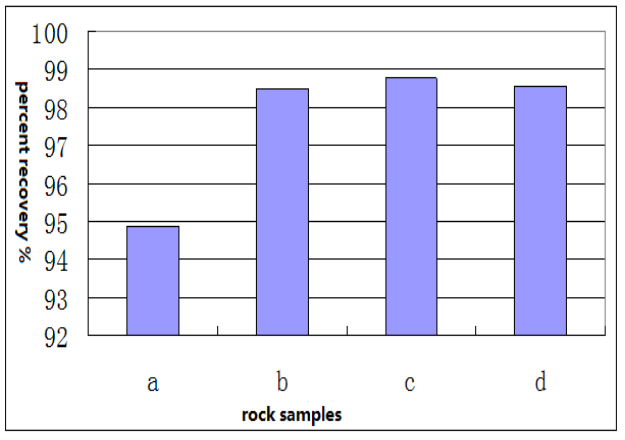

Figure 1. Four rock sample recovery rate in the water

Wherever Times is specified, Times Roman or Times New Roman may be used. If neither is available on your word processor, please use the font closest in appearance to Times. Avoid using bit-mapped fonts if possible. TrueType 1 or Open Type fonts are preferred. Please embed symbol fonts, as well, for math, etc.

a. the showroom soft shale;

b.Lanhua000-7well TX52921.50 2921.62m rock sample;

c.zhangjia001-X3 井 TX52972.28 2972.35m rock sample;

d. Peng 1well S1I 2120.13 2121.03 m rock sample.

It can be seen from Fig. 1, in addition to the recovery rate test of the showroom soft shale is smaller the other three kinds of samples have the high recovery rate, and the three recovery rate is similar. Peng 1well S1I 2120.13 2121.03 m rock sample respectively in four kinds of drilling fluid to the rolling recovery test, the results shown in fig. 2

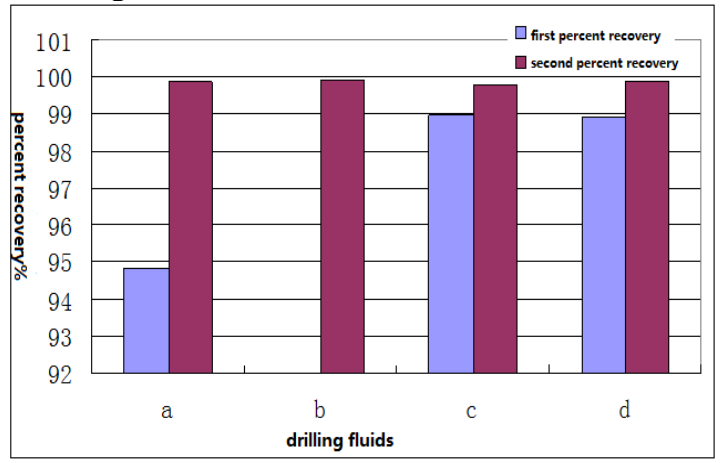

Figure 2. a. Potassium polysulfonate drilling fluid; b. oil-based drilling fluid;

c. simulation oil-based drilling fluid I ;

d. simulation oil-based drilling fluid II

In a rolling recovery rate determination of oil based drilling fluid the sample weight is greater than the original sample, the reason may be in the rolling recovery rate test, oil base drilling fluid of certain substances sticking the sample and not cleaning off. From Fig. 2 researchers can see, the samples of twice recovery rate difference in four kinds of drilling fluid is very small, but once the recovery rate is related to drilling fluid viscosity and others property.

The procedure of rolling recovery rate test is much more, in the washing, drying, weighing operation will make error, when the recovery rate is lower, it is difficult to make the right evaluation to suppress the dispersion of drilling fluid. So for the poor dispersion of rock, in rolling 
recovery test, it is difficult to make an evaluation to drilling fluid inhibition the dispersion of shale.

\section{B. Drill fluid filtrate linear expansion test}

The test is to detect the inhibition ability of drilling fluid filtrate to shale expansibility with NP-01 type normal temperature expansion measuring instrument. The method is: take 10 grams of dried shale samples that through 100 mesh sieve, then under the pressure of $8 \mathrm{MPa}$ extrusion pressure sample, measured by vernier caliper pressure sample thickness. Putting the sample into cup with $100 \mathrm{ml}$ test liquid, install the instrument, determination of a certain time interval line expansion[7-8].

Use Peng 1 well S1I 2120.13 2121.03 $\mathrm{m}$ sample as the test rock samples, use NP-01 type normal temperature expansion measuring instrument to test the expansion line rate of rock sample in water and simulation oil-based drilling fluid

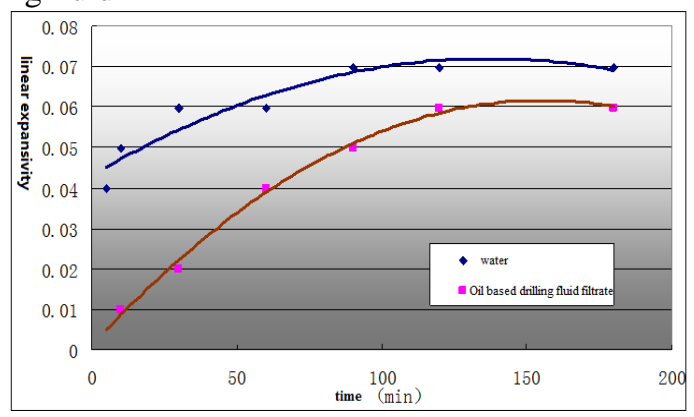

Figure 3. Shale line expansion rate and time relation curve

From the experiment results that the samples expansion is very poor, but the NP-01 type normal temperature expansion measuring instrument can accurately measure the expansion.

\section{The test bed of sand}

The test bed of sand use visual sand bed filtration instrument to observe that the drilling fluid can into the sand bed pore and quickly form blocking membrane to prevent drilling fluid invade further[9]. Determining steps and method: taking $200 \mathrm{ml}$ sand that though 20 to 40 mesh into the cylinder organic glass tube and oscillate tube to make the sand flat by hand, then along the tube wall to slowly pour into $300 \mathrm{ml}$ of mud, sealed, put the cylinder tube on bearing to seat and screw down set a big measuring cylinder under the cylinder tube, open the pressure valve, make pressure quickly reach to $0.7 \mathrm{MPa}$, then measure the 30 minutes filter loss and the depth that filtrate into the sand bed at room temperature

Four kinds of drilling fluid have been sand bed test, the test results shown in Table 2.
TABLE II.

THE TEST RESULTS OF THE TEST BED OF SAND

\begin{tabular}{|l|c|c|}
\hline \multicolumn{1}{|c|}{ drilling fluid } & $\begin{array}{c}\text { filter } \\
\text { loss }(\mathrm{ml})\end{array}$ & $\begin{array}{c}\text { filtration } \\
\text { depth (mm) }\end{array}$ \\
\hline $\begin{array}{l}\text { Potassiumpolysulfonate } \\
\text { drilling fluid }\end{array}$ & 0 & 28 \\
\hline oil-based drilling fluid & 0 & 25 \\
\hline $\begin{array}{l}\text { Imitation of oil-based } \\
\text { drilling fluid I }\end{array}$ & 2.5 & 100 \\
\hline $\begin{array}{l}\text { Imitation of oil-based } \\
\text { drilling fluid II }\end{array}$ & 0 & 24 \\
\hline
\end{tabular}

The test results in Table 2 show that the plugging ability of imitation of oil-based drilling fluids I is poor, and plugging ability of oil-based drilling fluids II imitation is better. This is because that the imitation of oilbased drilling fluids II increased $2 \%$ plugging agent. Test results indicate that the test bed of sand can make an evaluation for the plugging ability of drilling fluid.

\section{Immersion test}

Immersion test is take the rock into the immersion solution to soak, and then observe the changes after the rock samples was soaked[10]. Measure the size of core before and immerse to calculate the sample linear expansion rate. Samples can be immersed in different conditions, such as opening immersion, closing immersion. Opening immersion can also adopt static immersion and dynamic immersion

\section{E. Opening immersion}

\section{(1) Static immersion}

Ooze shale cut into pieces, take the core that retrieve at site in the core drilling machine get small cores that the diameter is $25 \mathrm{~mm}$, and use vernier caliper to measure the diameter and height; then put the rock into the beaker, add the soaked liquid immersion. At last, observe the phenomenon. Fig. 4 (a) is ooze shale soaked in water. This sample rock into water appeared cracks after 3 minutes and was collapsed after 9 minutes. Fig. 4 (b) is the sample rock of 001-X3 Zhang TX52972.28 2972.35m well soaked in water. The sample rock in the 80 degrees Celsius constant temperature water for three days and cannot find changes. The test shows that the ooze shale can use opening static immersion exposure

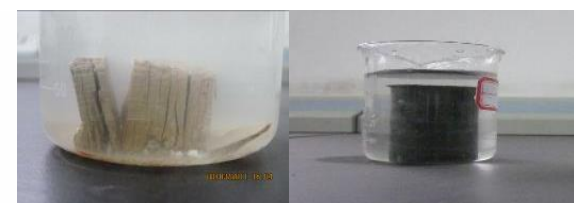

Figure 4. The condition of two samples soaked in water

(2) Dynamic immersion

Put the measured sample to a liquid immersion jar, placed in the 80 degrees Celsius constant temperature water, installing the mixer, In the case of stirring for 5 hours, then remove the core, observed soaked core changes, and use vernier caliper to measure the diameter and high degree. Fig. 6 is the condition of core that from Peng- 
1S12097.35 2097.47m well soaked in pseudo oil-based drilling fluid.

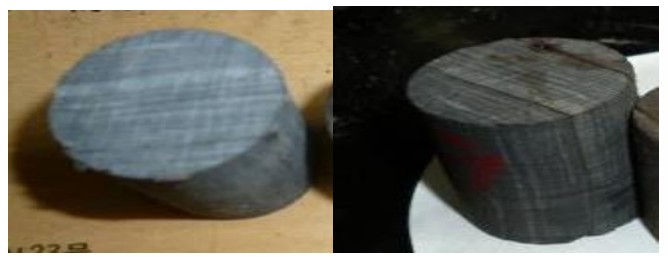

(a) Before soaking

(b) After soaking

Figure 5. the condition of the core soaked in Imitation of oil-based drilling fluid

In Fig. 5 can be observed for the formation of cracks in the core after soaking along the bedding plane, the diameter and height almost has no change. Core static immersion days are observed changes, but in the same temperature conditions, dynamic soak for a few hours can be observed in the core changes, it indicating that drilling fluid flow scour off the core of the filter cake, this will easy make the drilling fluid infiltrate to formation bedding face and form crack.

\section{F. Closing immersion}

Put the core to pint pot filled with soaking liquid and sealed, and then storing pint pot in $120^{\circ} \mathrm{C}$ incubator for 5 hours then taking the core, observed the phenomena of high temperature soaking and used vernier caliper to measure the diameter and height[7]. Put a crack core soaked in imitation of oil-based drilling fluid I first, then soaked in oil base drilling fluid, at last soaking in oil Imitation of oil-based drilling fluid II .

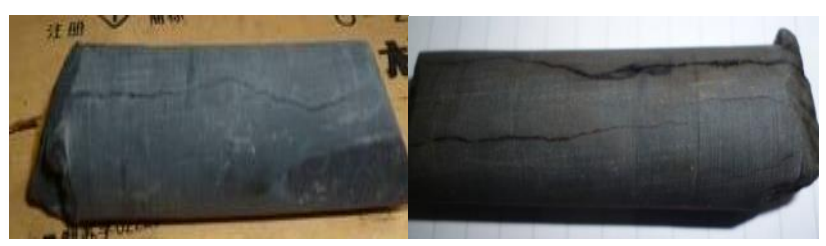

(a) Before soaking

(b)soaked in imitation of oil- based drilling fluid I

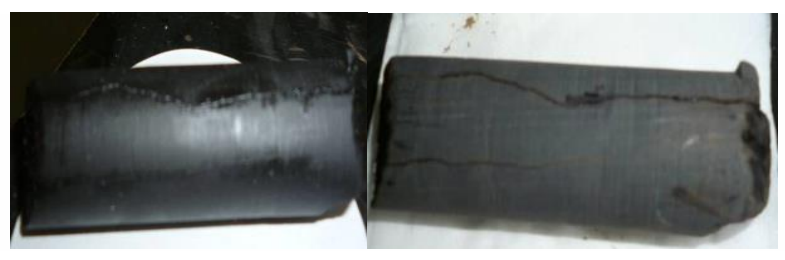

(c) soaked in oil-based

(d) soaked in imitation of

drilling fluid

oil-based drilling fluid II

Figure 6. The condition of the core soaked in many kinds of drilling fluid

From Fig. 6, it can be observed that original crack in the core expand after soaked in imitation of oil-based drilling fluid I, and produces two new cracks. After putting the core into the oil base drilling fluid, the two new cracks were not observed with the naked eye. The core get a new visible crack after soaking in imitation of oil-based drilling fluid III immersion results show that the oil base drilling fluid has good plugging micro fractures. The test results are consistent with the sand bed.

The additional small cores put into different drilling fluid for closing immersion. Immersion results are shown in table 3 .

TABLE III. CLOSED STATIC IMMERSION TEST RESULTS

\begin{tabular}{|c|c|c|c|c|}
\hline \multicolumn{2}{|c|}{ Core source } & \multirow[b]{2}{*}{ drilling fluid } & \multirow{2}{*}{$\begin{array}{l}\text { Linear } \\
\text { expansion } \\
\text { rate }(\%)\end{array}$} & \multirow[b]{2}{*}{ phenomenon } \\
\hline $\begin{array}{l}\text { Well } \\
\text { No. }\end{array}$ & formation & & & \\
\hline $\begin{array}{l}\text { Zhangjia } \\
\text { 001-X3 }\end{array}$ & $\begin{array}{l}\text { TX552971.7 } \\
0 \sim 2971.86 \mathrm{~m}\end{array}$ & $\begin{array}{l}\text { Potassium } \\
\text { polysulfonate } \\
\text { drilling fluid }\end{array}$ & Very small & Crack \\
\hline $\begin{array}{l}\text { Lianhua } \\
000-7\end{array}$ & $\begin{array}{l}\text { TX52921.50 } \\
\sim 2921.62 \mathrm{~m}\end{array}$ & $\begin{array}{l}\text { Potassium } \\
\text { polysulfonate } \\
\text { drilling fluid }\end{array}$ & 10.3 & $\begin{array}{c}\text { The } \\
\text { appearance } \\
\text { has not } \\
\text { changed }\end{array}$ \\
\hline peng1 & $\begin{array}{l}\mathrm{S} 1 \mathrm{I} 2120.13 \sim \\
2121.03 \mathrm{~m}\end{array}$ & $\begin{array}{l}\text { oil-based } \\
\text { drilling fluid }\end{array}$ & $\begin{array}{c}\text { Little } \\
\text { expansion }\end{array}$ & $\begin{array}{l}\text { The original } \\
\text { crack is } \\
\text { visible, but no } \\
\text { cracks along } \\
\text { the crack }\end{array}$ \\
\hline peng1 & $\begin{array}{l}\mathrm{S} 1 \mathrm{I} 2120.13 \sim \\
2121.03 \mathrm{~m}\end{array}$ & $\begin{array}{l}\text { Imitation of } \\
\text { oil-based } \\
\text { drilling fluid } \\
\text { I }\end{array}$ & $\begin{array}{c}\text { Little } \\
\text { expansion }\end{array}$ & $\begin{array}{l}\text { Along the } \\
\text { crack } \\
\text { dehiscence }\end{array}$ \\
\hline peng1 & $\begin{array}{l}\mathrm{S} 1 \mathrm{I} 2120.13 \sim \\
2121.03 \mathrm{~m}\end{array}$ & $\begin{array}{l}\text { Imitation of } \\
\text { oil-based } \\
\text { drilling fluid } \\
\text { II }\end{array}$ & $\begin{array}{c}\text { Little } \\
\text { expansion }\end{array}$ & $\begin{array}{l}\text { Along the } \\
\text { crack } \\
\text { dehiscence }\end{array}$ \\
\hline
\end{tabular}

Note: the line expansion is the line expansion of vertical bedding face

Using the samples of Peng 1 well S1I2120.13 2121.03 $\mathrm{m}$ for drilling fluid filtrate line expansion test, the determination results show that the sample line expansion rate is very small. But the expansion of Lianhua well 000-7 TX52921.50 2921.62m rock is larger.

\section{CONCLUSION}

(1) The shale rolling recovery test can detect the inhibition ability of drilling fluid for shale dispersion. The progress of method for the determination has big error, to the poor dispersion of rock sample for rolling recovery test, it is difficult to evaluate the ability of drilling fluid for shale dispersion

(2) The NP-01 type normal temperature expansion measuring instrument has higher accuracy, it can measure of poor expansion shale

(3) The sand bed test can detect the ability of the drilling fluid plugging shale fractures and pores, the test results and the results of drilling fluid immersion is consistent.

(4)Immersion test can be detection of drilling fluid work filtrate into the shale. It can be rough calculation about linear expansion rate, and detect plugging ability of drilling fluid. According to the characteristics of drilling shale formation to select the suitable soaking conditions. It can make a comprehensive evaluation for drilling fluid inhibition 


\section{ACKNOWLEDGMENT}

Fund Project: Chongqing University of Science and Technology graduate student science and technology innovation project YKJCX2014009

\section{REFERENCE}

[1] LIU Bin,ZHANG Xianming. Drilling fluid inhibiting performance evaluation standard research[J]. Drilling \& Production Technology, 1997,20(2) : 57-62.

[2] XU Tongtai,ZHAO Zhongju. The early 21 st century foreign drilling and completion fluids technology[M].Beijing: Petroleum Industry Press, 2004:50-55.

[3] Chenevert M E,oslsungu S O. Shale/mud Inhibition Defined with Rig-site Methods SPE Dirlling Engineering September 1989

[4] Carden R s . Technology Assessment of Vertical and Horizontal . Air Drilling Potential in the United
States . DOE/MC/28252-3514 the National Technical In Formnation Service. US, 1993: 1-6

[5] ZHAO jiangang SUNpeng WANGqi. Study on test method of shale swelling inhibitor[J] drilling fluid and comepletion fluid 2013,30(4),42-46

[6] YAN Jienian,LUO Jiansheng. Comprehensive Evaluation of the effect of anti-sloughing drilling fluid[J]. Journal Of The University Of Petroleum, 1999,23(1):31-34.

[7] YAN Jienian Drilling fluid technology[M]ShanDong China University of Petroleum, 2006:236-237

[8] ZHENG Xiuhua. Drilling performance evaluation and design guide book[M]. Beijing: China University of Petroleum,2005:31-48.

[9] HUAzhongyao Development and evaluation of shale inhibitors[J] chemical engineering of oil\&gas 2010,39(3),253-256

[10] LUO chunzhiL aboratory study on inhibition of drilling fluids and treatment agents evaluation[J] petroleum drilling techniques $2000,28(1), 35-37$ 